\title{
AN ANALYSIS OF STUDENTS' DIFFICULTIES IN USING ENGLISH INTONATION AT GRADE EIGHT OF SMP NEGERI 2 PEMATANGSIANTAR
}

\author{
Christian Neni Purba ${ }^{* 1}$, David Togi Hutahaean*2, Herman*3, Hilman Pardede*4, \\ $\underline{\text { bochubojg2@gmail.com }}^{* 1}$, davidhutahaean138@ gmail.com ${ }^{* 2}$, herman@uhn.ac.id $^{* 3}$, \\ hilmanpardede@yahoo.com ${ }^{* 4}$, \\ English Education Department ${ }^{* 1,2,3,4}$, University of HKBP Nommensen, Medan, \\ Indonesia ${ }^{* 1,2,3,4}$
}

\begin{abstract}
This research is raised in order to investigate the students' difficulties in using English intonation. As foreign language, students always face problems whether in pronouncing or listening that related to the pronunciation of the word. Pronouncing also refers to the intonation in conversation. Problem stated in this research as follow: What are the students' difficulties in using English intonation? It focuses on the students' intonation in a conversation, which consists of rising tone, falling tone and level tone. To answer the problem above, this research follows some theories, namely: Allen (1954), Haycraft (1971), Jones (1979), and Roach (2000). Descriptive qualitative research was conducted to answer the research problem. The participants were 10 second year students of SMP Negeri 2 Pematangsiantar, and the object was the student's intonation. The technique of collecting data follows audio method or what is called recorded voice data. The data is analyzed by drawing the terminal contour of students' intonation. The result of this research was there are three difficulties of students in using English intonation, namely: (1). Difficulty in using level tone, (2). Difficulty in using rising intonation (3). Difficulty in using falling intonation. This research finding recommends both teacher and students to take responsibility in overcoming those difficulties.
\end{abstract}

Keywords: Falling tone, intonation, level tone, pronunciation, rising tone

DOI: https://doi.org/10.31943/wej.v4i1.76

\section{INTRODUCTION}

In using language, the most important thing to be paid more attention is the using of the pronunciation and the intonation. Pronunciation and intonation are interconnected one to other and they play main role in speaking skill, especially in communication. Harmer (2007:281) as cited in Herman (2016:1) stated that pronunciation is the way we make sounds of the language how and where we place the stress, and how we use pitch and intonation to show how we are feeling and what we mean. This means that 
human uses the intonation to express the feeling and purpose of the speaking. But the reality, humans are difficult to use the correct intonation, especially for beginner or learners of English as foreign language, and they found it hard to be implemented in the communication. The previous research done by Rusadze and Kipiani (2015) entitled Intonation difficulties in non-native languages deals with the intonation difficulties in non-native languages. Poor pronunciation can make a foreign language learner very difficult to understand. Language teachers have lately become more aware of this and have shifted the focus of their pronunciation teaching. It is therefore crucial for language teachers to be aware of current research findings in the area of foreign (second) language learning. Many teachers find intonation difficult to teach. As a result they may avoid it. But intonation can be fun to work with and it can make other language areas easier to teach. Intonation is important to learn in conveying someone's mind. Speakers must use correct intonation, so listener can understand what the speakers mind.

According to Haycraft (1971:1-2), Intonation is the tune of a sentence, comparable with the rise and fall of the tune in a piece of music. Intonation is the, movement of the voice, between high and low pitch. English has two basic tunes, they are: 1) ultimately falling, and ultimately rising. The term of intonation refers to the way the voice goes up and down in pitch when we are speaking. It is a fundamental part of the way we express our own thoughts and it enables us to understand those of others. Intonation gives clues about the attitude of the speaker or how he feels about what he is saying. When listening to people speaking, we get clear messages about their attitude from the ways things are said. On the other hand, intonation is changing pitch of voice. When the pitch of voice rises we have a rising intonation; when it falls we have falling intonation; when it remains on one note for an appreciable time, we have level intonation (Jones, 1979: 275).

Common difficulties with intonation according to Haycraft (1971:71) are: 1).Wide voice range, This is a problem with students of any nationality. It is rarely caused by a physical impediment; it is normally shyness and suspiciousness and can be quickly overcome. 2). the falling tone of the last stressed syllable, this is another problem connected with a narrow voice range and is corrected by increasing the range. 3). final rising tone. 4). sentences of two or more stresses. 5). the level tone. 6). pitch needed for the first stressed syllable.

Based on the researchers' experience in teaching practice (PPL) of SMP Negeri 2 Pematangsiantar, it is found that they couldn't understand what his/her friend message due to the incorrect intonation. For example, when they were instructed to read the text, they often did mistakes in pronouncing the word. For instance, word "week" /'wi:k/ but they were pronounced /'wIk/, word "weak" /'wi:k/ also pronounced /'wIk/. That's why the researchers are interested to investigate the students' difficulties in using English intonation of the second year students at SMP Negeri 2 Pematangsiantar. 


\section{LITERATURE REVIEW}

\section{Definition of Intonation}

According to Haycraft (1971:1-2), intonation is the tune of a sentence, comparable with the rise and fall of the tune in a piece of music. Intonation is the, movement of the voice, between high and low pitch. English has two basic tunes, they are: 1) ultimately falling, and ultimately rising. Similarly, Roach (2000:150) defines "intonation as the pitch of the voice". Only in very unusual situations do we speak with fixed, unvarying pitch and we speak normally the pitch of our voice is constantly changing. In short, the most important tasks in analyzing intonation is to listen to the speaker's pitch and recognize what it is doing.

English intonation has five types of tones; they are falling, rising, fallingrising, rising-falling, and level. In analyzing intonation, tone unit is needed. Every tone unit has tonic syllable (TS). Tonic syllable is a syllable which carries a tone. And if the tonic syllable carries not only a tone but also a type of stress, then it will be called as tonic stress.

Tone unit has three components; they are head $(\mathrm{H})$, pre-head $(\mathrm{PH})$, and tail (T). The head is all of that part of a tone unit that extends from the first stressed syllable up to (but not including) the tonic syllable. It follows that if there is not stressed syllable before the tonic syllable, there cannot be a head. The pre-head is composed of all the unstressed syllables in a tone-unit preceding the first stressed syllable. Any syllables between the tonic syllable and the end of the tone-unit are called the tail.

To illustrate this more fully, a passage is provided below:

|| and then 'nearer to the front|| on the left| there is a 'bit of forest | 'coming 'down to the waterside $\|$ and then a 'bit of a bay\|

The structure can be marked as follows:

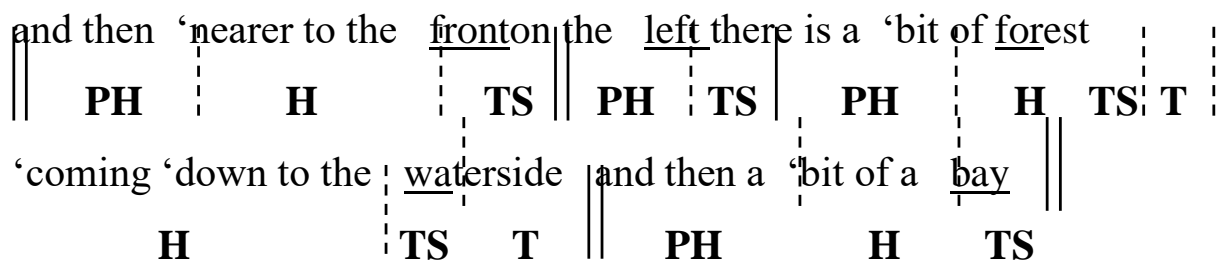

Allen (1954:39) defines intonation as "the melody of speech, the changing pitch of the voice". It is to certain extent controlled by stress, for important changes of pitch occur only on stressed syllables. The English intonation can be classified under two types. Both normally begin with the first stressed syllable fairly high, and fall step wise from stress until the last significant (meaningful) stress is reached. Type 1 fall, 
remaining low for any further unstressed syllables; type 2 rise from a low tone, continuing the rise for any further unstressed syllable.

Jones (1979:275) explains intonation may be defined as "the variations which take place in the pitch of the voice in connected speech, i.e. the variation and $\backslash$ pitch of the musical note produced by the vibration of the vocal cords". Intonation is quite different thing from stress. In ordinary speech the pitch of the voice is continually changing. When the pitch of the voice rises we have a rising intonation; when it falls we have a falling intonation; when it remains on one note for an appreciable time, we have level intonation. Based on the explanation above, intonation generally is the changing pitch of our tone from high to low, and rising to falling.

\section{Types of Intonation.}

Jones (1979:275) classifies English intonation into three categories, they are: 1). rising intonation $(/), 2)$. falling intonation (\), and 3). level intonation (-). The detail explanation of those three categories of intonation can be seen below:

\section{Rising Intonation}

Rising intonation is normally used in:

a. Yes-No Questions

For example:

1. Are you happ

2. Do you study English everydin?

3. Will you go to school to morrow?

4. Have you met him?

5. Did you go to the party yesterday?

\section{Falling Intonation}

Falling intonation is normally used in:

a. W-H Questions

For example:

1. Where do you hive?

2. What do you want?

3. Which do you like best?

4. Why do you complain

5. How far is your destination? 
b. Positive statement

For example:

1. We are going to the movies tonight.

2. She will celebrate her seventeenth birthday next meek.

3. Tom has lived in London for five years.

4. Theif plane is arriving at nine in the morning.

5. The church was more crowded than usual.

c. Negative statement.

For example:

1. We are not going to the movies tonight.

2. She will not celebrate her seventeenth birthday next meek.

3. Tom has not lived in London for five years.

4. Their plane is not arriving at nine in the mor hing.

5. The church was not more crowded than usulal.

\section{Level Intonation}

Level intonation is a series of word phrases or clauses in a sentence. This tone is certainly used in English, but in a rather restricted context: it almost always conveys (on single- syllable utterances) a feeling of saying something routine, uninteresting or boring. A teacher calling the names of pupils from a register will often do so using level tone on each name, and the pupils are likely to respond with "yes" ( in level intonation) when their name is called.

\section{Wave Intonation}

Allen (1954:90) provides that wave intonation consists of Falling-Rising Intonation and Rising-Falling Intonation.

a. Falling - Rising Intonation

The Falling-Rising Intonation is used a lot in English and has some rather special functions. It is to describe limited agreement or responses with reservations. 
Example:

1. I don't want to be hate ( . . . so please excuse me hurrying away so soon)

2. She never drinks tefa ( . . . so it's useless to offer her any)

3. Well, I don't agree ( . . . though I do understand your point of view)

4. I don't believe it's tryle (.. in spite of all the rumors)

5. I only had threk ( $\ldots$ and you knew that wasn't enough)

b. Rising - Falling Intonation

This is used to convey rather strong feelings of approval, disapproval or surprise. It is not usually considered to be an important tone for foreign learners to acquire, although it is still useful practice to learn to distinguish it from other tones.

Example:

1. We walked home because we missed the train.

2. Afterwards, we went home.

3. If I put it up there, it will fall off.

\section{Combined Intonation}

Allen (1954:59) also formulates combined intonation which usually occurs on the two or more clauses. The uses of combined intonation are as follows:

a. Sentences beginning with subordinate clause have rising intonation and followed by falling intonation for the main clause Example:

1. When he canne, I asked him to wait.

2. $\overline{\text { After the }}$ ganne, we had some taa.

3. Just as the train was starting, he jumped in.

4. Since you refuse to help, I must do it alone.

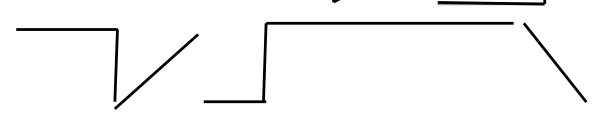


5. If you like, I'll send the car for you.

b. Sentences beginning with main clause have falling intonation and followed by rising intonation for the subordinate clause. It is particularly common with conditions spoken in a hesitant manner.

Example:

1. I eat steak, when I can get it.

2. I'd buy a new one, if I could afford it.

3. There'll be nothing left, after you've had yours.

4. They'll have to cross by deat, until the bridge is built.

5. I always clean my teeth, after $\overline{\text { eating }}$.

Combined intonation is also used in alternative questions, enumeration things and compound sentences.

Example of alternative question:

1. Shall we drixe or shall we go by train?

2. Do you like tea or cofffee or cocoa?

Example of enumeration things:

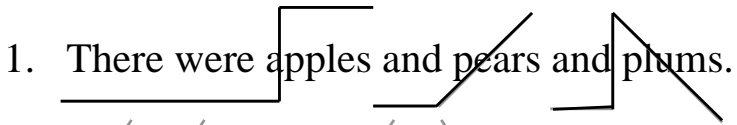

2. Onie, two three, four, five.

xample of compound sentence:

1. I'd just bought a new pair of gloves and was walking out of the shep.

2. I sent him a why but he came back again.

\subsection{Intonation of Imperative}

In expressing imperative, Allen (1954:97) suggests that it has falling intonation if the sentence expresses command, and it has rising intonation if the sentence expresses polite or friendly request. 
Example:

1. Bring me a ckair!

2. Wait a moment!

3. Let's try agan!

4. Don't ary!

5. Shut the dopr! $\overline{\text { Bring me a }}$ chair.

Wait a moment.

Let's try gazín.

Don't cry.

Shut the door.

\subsection{Intonation of Question Tag}

In its simplest form, the tag may be spoken on either falling or rising intonation. The choice mainly depends on the speaker's certainty of his fact (Allen, 1954:102).

1. Remark and tag both on falling intonation

This is used when the speaker feels reasonably sure that his remark is correct and the tag merely to invite the listener to agree with him.

- It's a fine day, isn't it?

- You came this motning, didn't you?

- Tdmorrow's Monday, isn't it?

2. Remark on falling intonation and tag on rising intonation

If the tag is spoken on the rising intonation, we understand that the speaker is less certain of his remark; it is presented more as a true question. The speaker suggests: "I believe that is so, but please correct me if I am wrong." By using this rising tag, he is asking the listener's opinion and would not be very surprised if he were contradicted.

- You can drive a dar, can't you?

- We last met in Mach, didn't ye?

- You live in Chelsea, don't you?

3. Remark on rising intonation and tag on falling intonation The remark itself is made more tentative by using rising intonation, but falling intonation of the tag shows that the speaker is pretty confident that his listener will not contradict. 
- You won't minid, will you?

- You'll bring it back, won't yqu?

4. Remark and tag both on rising intonation

The rising tag makes the tentative remark even more uncertain; the speaker seeks the listener's assurance that his remark is correct. It is almost a real question.

- This one isn'tyours, is $j t$ ?

- It's not toolate, is it?

- You'd like td speak to him, wouldn't your?

\section{Intonation of Parentheses}

Expressions of a parenthetical nature have no particular intonation of their own. They share the intonation that the main sentence would have if the parentheses were not there. Thus a parenthesis occurring at the end of a sequence requiring Falling Intonation is said on low level pitch (Jones, 1979: 316). Example:

- “Attack with a sharpen steel!" King Arthur ordered.

- "I can'thelp it," he said impatiently

- "Will you marry nue?" Susan asked

\section{Function of Intonation.}

According to Roach (2000:183-184), function of intonation can be divided into: 1. Attitudinal Function.

Intonation enables us to express emotions and attitudes as we speak, and this adds a special kind of meaning to spoken language. The notion of expressing an emotion or attitudes is itself a more complex one than is generally realized. Our pronunciation of different ways for example, if the sentence was " $I$ want to buy a new car' and you were to say it in the following ways: "pleading", "angry", "sad", "happy", "proud", it is certain that at least some of your performances will be different from some others.

2. Accentual Function

Intonation helps to produce the effect of prominence on syllables that need to be perceived as stressed, and in particular the placing of tonic stress on a particular 
syllable marks out the word to which it belongs as the most important in the toneunit.

\section{Example:}

a. I have 'plans to ، leave (I am planning to leave)

b. I have ،plans to -leave (I have some plans/drawings/diagrams that I have to leave)

\section{Grammatical Function}

The listener is better able to recognize the grammar and syntactic structure of what is being said by using the information contained in the intonation.

It is usual to illustrate the grammatical function by inventing sentences which when written are ambiguous, and whose ambiguity can only be removed by using differences of intonation.

Example:

a. 'Those who `sold -quickly ، made a ،profit. (Meaning: A profit was made by those who sold quickly)

b. 'Those who -sold „quickly made a ، profit. (Meaning: A profit was quickly made by those who sold).

The difference caused by the placement of the tone unit boundary is seen to be equivalent to giving two different paraphrases of the sentences.

\section{Discourse Function}

Looking at the act of speaking in a broader way, we can see that intonation can signal to the listener what is to be taken as "new" information and what is already "given", can suggest when the speaker is indicating some sort of contrast or link with material in another tone- unit and, in conversation, can convey to the listener what kind of response is expected.Example:

A: Have you got any free time this morning?

B: I might have later on if that meeting's off.

A: They were talking about putting it later.

B: You can't be sure.

Each sentence could be studied in isolation and be analyzed in terms of grammatical construction, lexical content and so on. But it is obvious that the sentence form part of some larger act of conversational interaction between two speakers; the sentences contain several references that presuppose shared knowledge (e.g. "that meeting" implies that both speakers know which meeting is being spoken about), and in some cases the meaning of a sentence can only be correctly interpreted in the light of knowledge of what has preceded it in the conversation (e.g. "You can't be sure")

\section{RESEARCH METHOD Research Design}


This research is designed to descriptive qualitative research. Keegan (2009:11) as cited in Herman (2016:4) stated that qualitative research is less easy to define. It explores questions such as what, why, and how many or how much. With the research context is the intonation, this research aims to describe the students' difficulties in using English intonation in speaking a dialogue, which consists of positive statement, negative statement, w-h question, and yes-no question. The participants of this research are 10 students -5 females and 5 males - of SMP Negeri 2 Pematangsiantar as the key informant of the research. These students are supposed to represent the other students to know their difficulties in using English intonation. To collect the data, the researchers use tape-recorder/mobile as instrument in gathering primary data. The researchers recorded the student's conversation, after that the researchers transcribe the primer data. The data collection of this research follows some steps: (1) The students make a dialog about Asking for Service, and Asking giving Rejecting Service from hand book English in Focus, which consists of positive statement, negative statement, w-h question, and yes-no question. (2) The students perform a dialogue which entitle "Asking for Service, and Asking for Rejecting Service. It is taken from the students' handbook "English in Focus VIII: Published by Pusat Pembukuan Depnas. (3) the researchers record the students' speaking by using tone recorder or mobile phone. The length of record for one student depends on the student's ability in Speaking. For data analysis, the researchers follows the steps: (1) Listening to the recorded data . repeatedly. (2) Drawing the terminal contour of skills intonation. (3) Analyzing the students' intonation which has incorrect form and giving the correct form. (4) Drawing conclusion

\section{FINDINGS AND DISCUSSION}

In this research, the researchers presented 2 data as sample to be presented in the data analysis here.

\section{Data 1}

Adila : Hi, rapma

Rahma: Hi Adtila, What are youdoing?

Adila : I am looking for mydog.

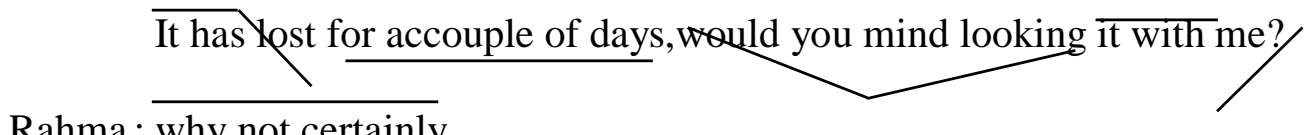

Rahma: $\overline{\text { why not.certainly }}$

Adila : let's findit

Analysis Data 1: 
In data 1, Dila in speaking "hi Rahma using falling tone in last sentence, whereas to should word Rahma using level tone. In sentence two for Rahma in the word "Adila" using falling tone. In the sentence three Adila speaking "I'm looking for my dog" in the last sentence toward level tone. And "it has lost for a couple of days, would mind looking it me? Students made mistake in using tone for sentence "why not certainly" towards students using level rising for sentence and then for sentence "let's find it" toward students intonation rising tone. So, in the conversation students made mistake in using falling tone.

\title{
Data 2
}

Alif : Could you helpme?

Jainap : $\overline{\text { Certainly. }}$. What can Kdo for you?

Alif : Can you takdmy dictionary over there?

Jainap : $\overline{\text { Of course. }} \overline{\text { Here you are }}$.

Alif : $\overline{\text { Thanks }}$,

Jainap : Don't mention it.

Analysis Data 2:

In data 2, sentence one, "help" the students should use falling tone not rising tone. And the sentence two, Jainap speake "certainly" for (only) using falling tone and "what can I do for you" intonation using rising tone.

\author{
Alif : Could you help me?

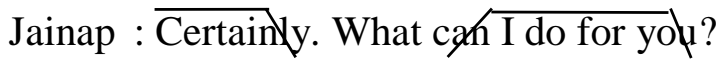 \\ Alif : Can you fake my dictionary over there? \\ Jainap : $\overline{\text { Of course }} . \overline{\text { Here you are. }}$ \\ Alif : Thanks' \\ Jainap : Don’t mentionit.
}

After analyzing the data, the researchers found the students' difficulties in using English intonation at SMP Negeri 2 Pematangsiantar covers difficulty in using 
correct juncture; difficulty in using rising intonation for the first clause and falling intonation for the second clause in a compound sentence; difficulty in using falling intonation for w-h question and rising intonation for yes-no question; and last is difficulty in determining pitch and stress of a syllable. After analyzing the data, the researchers tried to draw the factor that made the students became difficulty in using the intonation. Some of the factors are shyness and doubt. These problems should be overcame earlier in order to avoid the voice faltered. Other problem was the students did not know the use of intonation in yes/no question and WH- questions. These happen because of the teacher did not explain and pronounce the sentence in the form of questions in a good intonation. Sometimes, the wh- questions can be rising and also falling. Meanwhile, the yes/no question is a must to have a rising intonation. Besides that, the stress and high/low pitch in the sentence to be pronounced are also not being used in a good way.

The researchers would like to discuss students' problems in using the English intonation in speaking skills. The previous point above was clear that difficulties drawn after analyzing the data were difficulty in using correct juncture; difficulty in using rising intonation for the first clause and falling intonation for the second clause in a compound sentence; difficulty in using falling intonation for w-h question and rising intonation for yes-no question; and last is difficulty in determining pitch and stress of a syllable. Based on the finding in this research, the researcher assumed that there was a difference between the results of the research done by Herman (2016). The similarity was slight for the pronunciation and intonation in speaking. But the differences were in the theory and findings. The theory used by Herman was Kelly (2000), meanwhile this research used theory by Allen (1954) and Roach (2000). The result was researcher found that the most difficult position in pronouncing the English labiodentals sounds was final position in sound / v /. This result was also influenced by the basic intonation learned by the students was not completely good. In short, the researchers emphasized that the comprehending of intonation in English is really important in order to have a good communication.

\section{CONCLUSION}

After analyzing the students' terminal contour, the researchers concluded that difficulty in using correct juncture, rising intonation for the first clause and falling intonation for the second clause in a compound sentence, using falling intonation for $\mathrm{w}-\mathrm{h}$ question, and rising intonation for yes-no question, with determining pitch and stress of a syllable were the main problems faced by the students. By having this conclusion, the researchers hope that the teaching for the speaking skill, especially in pronunciation and intonation must be the first priority for the learners (beginners) in order to be able to communicate, share feeling and purposes in the right way of communication. Furthermore, the researchers want to suggest to English teachers. The teacher should introduce stress to class of beginner. Teachers must be able to decide where the stress is to be placed in a sentence, it must be correct in its context, 
and he should be able to repeat the sentence several times correctly stressed, in order that the students may learn it from him. The teachers also should be able to detect a falling intonation from a rising intonation in his own voice as well as in a student's. The intonation pattern can be demonstrated by movement of the arm or by drawing the intonation on the blackboard. Last but not least, the teacher should speak and read at a normal speed so that the students will not get used to a pace different to that which they hear outside the classroom.

\section{REFERENCES}

Allen, W.S. (1954). Living English Speech. London: Longman Group Ltd.

Ary, D., Jacobs, L.C., and Asghar R. (1979). Introduction to Research in Education. Second Edition, Holt, Rinehart and Winston, Inc

Couper, G. (2011). What makes pronunciation teaching work? Testing for the effect of two variables: socially constructed metalanguage and critical listening, Language Awareness, 20:3, 159-182, DOI: 10.1080/09658416.2011.570347

Foote, J.A., Trofimovich, P., Collins, L. \& Urzúa, F.S. (2016). Pronunciation teaching practices in communicative second language classes, The Language Learning Journal, 44:2, 181-196, DOI: 10.1080/09571736.2013.784345

Georgiou, G.P. (2019). EFL teachers' cognitions about pronunciation in Cyprus, Journal of Multilingual and Multicultural Development, 40:6, 538-550, DOI: $\underline{10.1080 / 01434632.2018 .1539090}$

Haycraft, B. (1971). The Teaching of Pronunciation. London: Longman Group Ltd.

Herman. (2016). Students' Difficulties in Pronouncing the English Labiodental Sounds. Communication and Linguistics Studies. Vol. 2, No. 1, 2016, pp. 1-5. doi: 10.11648/j.cls.20160201.11. Available at: http://www.sciencepublishinggroup.com/journal/paperinfo?journalid=357\&pa perId=10016673

Jones, D. (1979). An Outline of English Phonetics. New Delhi: Kalyani Publishers.

Kanno, M. (2003). Thoughts on how to play in tune: pitch and intonation, Contemporary Music Review, 22:1-2, 35-52, DOI: $\underline{10.1080 / 0749446032000134733}$

Kennedy, S. \& Trofimovich, P. (2010). Language awareness and second language pronunciation: a classroom study, Language Awareness, 19:3, 171-185, DOI: $\underline{10.1080 / 09658416.2010 .486439}$ 
Mitrofanova, Y. (2012). Raising EFL students' awareness of English intonation functioning, Language Awareness, 21:3, 279-291, DOI: $\underline{10.1080 / 09658416.2011 .609621}$

Roach, P. (2000). Techniques for the Phonetic Description on Emotional Speech. Newcastle. Northern Ireland: Cambridge University Press.

Rusadze, I. and Kipiani, S. (2015). Intonation difficulties in non-native languages. Published at http://atsu.edu. ge/EJournal/HENTI/ebook/New/RusadzeIrma.pdf

Sare, S. (1966) . English in our Languages. London: Longman Group Ltd.

Shabani, K. \& Ghasemian, A. (2017). Teacher's personality type and techniques of teaching pronunciation, Cogent Education, 4:1, DOI: $\underline{10.1080 / 2331186 X .2017 .1313560}$

Verdugo, D. R. (2006). A Study of Intonation Awareness and Learning in Non-native Speakers of English, Language Awareness, 15:3, 141-159, DOI: $\underline{10.2167 / 1 a 404.0}$

Yangklang, W. (2013). Improving English stress and intonation pronunciation of the first year students of Nakhon Ratchasima Rajabhat University through an Elearning. Procedia - Social and Behavioral Sciences 91 ( 2013 ) $444-452$ 